\title{
Effects of Dietary Fumonisin B1 on Haematology and Growth Performance of the Clariid FishHeterobranchus longifilis
}

\author{
Adeyemo, Bolade Thomas ${ }^{12^{*}}$; Tiamiyu, Lateef Oloyede ${ }^{2,3}$; \\ Ayuba, Victoria Ogeh ${ }^{2}$; Cheikyula, Joseph Orkuma ${ }^{2}$ \\ 1. Department of Veterinary Pathology, Faculty of Veterinary Medicine,University of Abuja, PMB 117 Abuja, \\ Nigeria. \\ 2. Department of Fisheries and Aquaculture, College of Forestry and Fisheries, University of Agriculture \\ Makurdi, PMB 2373 Makurdi, Nigeria. \\ ${ }^{3 .}$ Department of Aquaculture and Fisheries, Faculty of Agriculture, Universityof Ilorin, PMB 1515 Ilorin, \\ Nigeria.
}

\begin{abstract}
Mycotoxins are secondary metabolites produced by fungi. There are evidence that mycotoxins cause pathologies including growth reduction in aquatic species. Experiments were carried out to determine the effects of fumonisin B1 (FB1) on haematology and growth performance of Heterobranchuslongifilis catfish. Fifteen 1,000 L capacity tanks divided into five groups made of three replicates each were stocked with 30

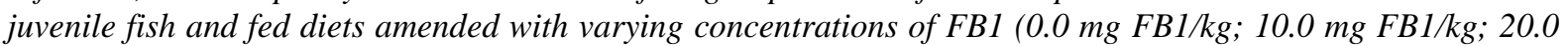
$\mathrm{mg} \mathrm{FB1/kg;} 40.0 \mathrm{mg} \mathrm{FBI/kg}$ and $80.0 \mathrm{mg} \mathrm{FBI/kg}$ ). At time points 7; 14; 28 and 56 days of feeding, the fish were randomly sampled from each tank, weighed, length measured and bled for haematology. Results obtained shows that except for the haemoglobin concentration of fish fed diet containing $40 \mathrm{mg} \mathrm{FBl} / \mathrm{kg}$, there were no significant difference $(P>0.05)$ in the erythrocytes count, haemoglobin concentration and haematocrit at 7 days of feeding. At 14 days of feeding, the erythrocytes counts of fish fed the control diet, was not significantly different $(P>0.05)$ from those fed diets containing 10.0 and $20.0 \mathrm{mg} \mathrm{FBl} / \mathrm{kg}$ but was significantly different from that of fish fed 40.0 and $80.0 \mathrm{mg} \mathrm{FBI/kg}$. Also, the erythrocytes counts and haemoglobin concentration of fish fed diet containing $40 \mathrm{mg}$ FB1/ $\mathrm{kg}$ do not differ significantly compared with those of fish fed diets containing $80 \mathrm{mg}$ FBl $/ \mathrm{kg}$. ANOVA reveals significant difference $(P<0.05)$ in the haematocrit of fish fed the control diet compared with fish fed diets containing FB1; Turkey post hoc shows the haematocrit of fish fed diet containing 10.0 and $20.0 \mathrm{mg} \mathrm{FBI} / \mathrm{kg}$ do not differ significantly $(P>0.05)$ but however, significantly $(P<0.05)$ differ from those of fish fed diets containing amounts $\geq 40.0 \mathrm{mg} \mathrm{FB1/kg}$. Dietary FBI caused leucocytopeania that was dependent on the concentration of the FBI in the diet as on the duration of feeding on the diets. Growth performance indices were significantly affected by the presence of FBI in the diets. In conclusion, this study showed diets containing fumonisin B1 levels $\leq 20 \mathrm{mg} \mathrm{FB1/kg} \mathrm{produced} \mathrm{the} \mathrm{least} \mathrm{pathology} \mathrm{in} \mathrm{juvenile}$ Heterobranchuslongifilis catfish.
\end{abstract}

Keywords: Fumonisin B1, Heterobranchuslongifilis, Growth performance, Haematology, Catfish.

\section{Introduction}

Fumonisins are metabolites produced by species of the filamentous fungus Fusarium (Fusarium verticiloides and F. proliferatum) (Gelderblom et al, 1998). About 28 homologues of the Fumonisins have been described (Bezuidenhou et al, 1988), of these fumonisin B1 (FB1) is reported to be the most common and most toxic (Voss et al, 2011). Whereas the Fumonisins have been reported to be present in several agricultural commodities (Binder et al, 2007; Walter and Marasas, 2001), animal and human health problems associated to the fumonisins are almost exclusively related to the consumption of maize and or products made from maize (Voss et al., 2007).

The chemical structure of the fumonisins has been reported to be similar to that of the sphingolipids (sphinganine and sphingosine); biochemically, the fumonisins competitively, inhibits the enzyme Ceramide synthase thereby causing a disruption of the de novo biosynthesis of Ceramide and Sphingolipids metabolism resulting in the promotion of the accumulation of Sphinganine and to a lesser extent, Sphingosine in tissues, blood and urine (Hascheck, 2006; Riley and Voss, 2006; Tardieus et al, 2006). The accumulation of Sphinganine in tissues have been reported to induce a pro-apoptotic, cytotoxic and growth inhibitory effects (Rauber et al, 2012; Voss et al, 2007), which elicits immunotoxicity, hepatotoxicity, nephrotoxicity and carcinogenicity in exposed animals (Theumer et al, 2002; Voss et al, 2002).

Two notable diseases/syndromes have been reported in animals fed FB1 contaminated feeds; Equine leucoencephalomalacia (Marasas et al, 1998) and Porcine pulmonary edema (Harrison et al, 1990). In fishes, the role of fumonisins as toxic agents remains unclear as conflicting reports concerning the effects of FB1 abound in scientific literature. For example, whereas Brown et al (1992), reported that the dietary exposure of Channel 
catfish (Ictaluruspunctatus) to $313 \mathrm{mg} \mathrm{FB1/kg}$ for five weeks produced minimal adverse effects; diets containing $20 \mathrm{mg} \mathrm{FB} 1 / \mathrm{kg}$ was reported to result in lower weight gain and a significant decrease in the haematocrit, erythrocytes and leucocytes counts of the same fish species (Lumlertdatcha et al,1995). Also, Pepeljnjak et al (2003), showed that long term exposure of Common Carp (Cyprinuscarpio) to dietary levels of up to $5 \mathrm{mg} \mathrm{FB} 1 / \mathrm{kg}$ resulted in adverse physiological effects in the liver and kidney of exposed fish. Petrinect et al (2004), observed that aside from the lesions in the liver and the kidney, dietary FB1 also induced deleterious effects such as increased endothelial permeability and dispersed nonspecific lesions in the endocrine and exocrine pancreas of exposed Common Carp (Cyprinuscarpio).

The Clariid fish Heterobranchuslongifilis constitute one of the largest group of cultured catfish species in Nigeria (FMARD, 2003). This fish is widely cultured in earthen ponds and in concrete tanks (Adeyemo and Umeakuana, 2011). The culture of clariid catfishes involves the utilization of feeds containing up to $30 \%$ maize as a source of energy (Tiamiyu et al, 2006); thereby inadvertently imposing the risk of the introduction of FB1 in the formulated diets (Voss et al, 2007; Bankole and Mabekoje, 2004). There is a paucity of reports on the effects of FB1 on the clariid fishes, this study therefore, was carried out to determine the effects of fumonisin B1 on the haematology and growth parameters of Heterobranchuslongifilisjuveniles after dietary FB1 exposure.

\subsection{Experimental Fumonisin B1}

\section{Materials And Methods}

Research grade FB1 used for the study was purchased from Sigma Aldrich (St Louis, M.O USA). Purity was ascertained by HPLC-fluorescence detection after derivatization with $o$-phthaldiadehyde (OPA, Sigma) to be greater than $98 \%$. Other chemicals and reagents were purchased commercially at the highest degree of purity available.

\subsubsection{Preparation of the FB1 stock solution}

Fumonisin B1stock solution was prepared by dissolving $1 \mathrm{~g}$ fumonisin B1 (Sigma chemicals St Loius, USA) with $1,000 \mu \mathrm{L}$ of acetonitrile-water (vol:vol) resulting in a $1 \mu \mathrm{L}: 1 \mathrm{mg}$ solution of FB1.

\subsubsection{Preparation of the Basal (Control) Diet and Experimental FB1 Amended Diets}

The basal diet was formulated according to Ayinla (2007), with slight adjustments, to meet the nutritional requirements of juvenile clariid fishes. Formulated feed was then subjected to proximate analysis to ascertain its nutritional status.

From the FB1 stock solution, the volume of solution needed to produce the experimental diets for the various FB1 inclusions were pipetted into $1,000 \mathrm{ml}$ beakers into which had been placed $200 \mathrm{ml}$ warm distilled water. After careful stirring, weighted portions of the starch binders were added, followed by the addition of the weighed portions of the basal diets ingredients and finally, pelletizing using a bench extruder. The finished feeds were oven dried at $65{ }^{\circ} \mathrm{C}$ for 5 hours, allowed to cool to room temperature analysed for FB1 content (MaxSignal ELISA Test Kit; Bioo Scientific, Austin USA) and packed in cellophane bags, labelled and there after stored at $4{ }^{0} \mathrm{C}$ until used.

\subsubsection{Experimental Design and Experimental Fish.}

Fifteen (15) 1,000 litre capacity tanks retrofitted with water inflow and out flow devices were divided into five groups made up of three replicates tanks each; these tanks were labelled groups A, B, C, D and E; with their respective replicates labelled A1, A2, A3; B1, B2, B3; C1, C2, C3; D1, D2, D3 and E1, E2, E3 respectively.

\subsubsection{Experimental Fish}

Four hundred and fifty (450) juvenile Heterobranchuslongifilis catfish were purchased from a commercial hatchery (Korede Farms Inc. Makurdi, Benue state Nigeria). The fish were transported in plastic vats to the aquatic research laboratory of the Department of Veterinary Pathology University of Abuja, were they were screened for the signs of disease, external lesions and presence of external parasites (Roberts, 2012). The fishes were then weighted $(151.64 \pm 2.11 \mathrm{~g})$, total length measured $(27.00 \pm 1.39 \mathrm{~cm})$ and there after randomly distributed into tanks at a stock density of 30 fish per tank for a 15 days period of acclimation. Stocked fish were then fed diets DA (Control, $0.0 \mathrm{mg}$ FB1/kg); DB (10.0 mg FB1/kg); DC (20.0 mg FB1/kg); DD (40.0 mg FB1/kg) and diet DE (80.0 mg FB1/kg) for 56 days. At time points 7, 14, 28, and 56 days, using a hand held net, the fish were individually weighed and total length measured. At these same time intervals, blood for haematological determinations were obtained from the fish by caudal veni-puncture (using a $23 \mathrm{G}$ needle fitted on a $5 \mathrm{ml}$ syringe). 
Effects of Dietary Fumonisin B1 on Haematology and Growth Performance of the Clariid Fishhe..

\subsubsection{Determination of Haematological Parameters}

The erythrocytes and leucocytes were manually enumerated using the Neubauer Counting Chamber after dilution of blood collected in ethylene diamine tetra acetic acid (EDTA) tubes with Dacies solution (Campbell, 2012; 2004). The haematocrit was determined by microhaematocrit method (Knowles et al, 2006) and the blood haemoglobin concentration was determined by the Cyanmethemoglobin method (Campbell, 2012).

\subsubsection{Determination of Growth Performance}

The effects of dietary fumonisin B1 on growth performance was determined by the evaluation of the Specific Growth Rate (SGR) and the Feed Conversion Ratio (FCR) after 56 days of feeding.

The specific growth rate was determined according to Arnanson et al (2009), using the formulae SGR = $100 \times\left[\left(\mathrm{InW}_{2}-\mathrm{InW}_{1}\right) / \mathrm{t}_{2}-\mathrm{t}_{1}\right]$. Were, $\mathrm{W}_{2}$ is weight attained after period of feeding on diet; $\mathrm{W}_{1}$ is weight at commencement of the feeding experiment; $t_{2}-t_{1}$ is the time period (in days) of feeding on the experimental diets.

The feed conversion ratio was calculated according to Sepahdar et al (2009), using the formulae FCR = Amount of feed eaten (dry weight) (g) / fish weight gain $(\mathrm{g})$.

\subsubsection{Determination of culture water parameter}

Water samples were collected at the beginning of the experiments and at every sampling time points for the determination of the water quality parameters as described by Boyd and Tucker (1992).

\subsubsection{Statistical Evaluation}

Data obtained from the experiments were analysed using a one way analysis of variance (Statistical Package for Social Sciences SPSS 20Software). Results giving $p$ values $\leq 0.05$ were considered significantly different and further analysed by Turkey-Kramer post hoc test. Difference between groups were considered statistically different for $p$ values $\leq 0.05$. Results were presented as Mean \pm Standard Deviation of the mean.

\section{Results \\ 3.1 Effects of Fumonisin B1 Diets on the Haematology of Heterobranchuslongifilis}

Table 1 shows the diet composition, proximate analysis and the fumonisin B1 contents of the control and the experimental diets. The proximate analysis reveals the control and the experimental diets are isocaloric and isonitrogenous; and the fumonisin contents varied from $2.37 \mathrm{mg} \mathrm{FB} 1 / \mathrm{kg}$ for diet D1 (control diet); $14.68 \mathrm{mg}$ FB1/kg (diet D2); $24.74 \mathrm{mg} \mathrm{FB1/kg} \mathrm{(diet} \mathrm{D3);} 43.04 \mathrm{mg}$ FB1/kg (diet D4); and $82.77 \mathrm{mg}$ FB1/kg (diet D5).

Table 2 depicts the results of the effect of dietary FB1 on the erythrocytes counts. It shows there was no significant difference $(P>0.05)$ in the erythrocytes counts of fish fed the control diets and those fed the diets amended with FB1, though there were marginal increases in the erythrocytes counts of fish fed the diet D4 and D5 seven days after the commencement of the dietary experiment. At 14 days of feeding diets amended with FB1, the erythrocytes counts of fish fed diet D4 and diet D5 were significantly different $(P<0.05)$ from those of fish fed the control diets (diet D1) and fish fed diets D2 and D3. At this same time interval, the erythrocytes count of fish fed diet D3 was not significantly different $(P>0.05)$ from those of fish fed diet D5; indicating that dietary FB1at $43.04 \mathrm{mg}$ FB1/kg elicited the same magnitude of response in terms of the erythrocytes count as dietary FB1 at $82.77 \mathrm{mg}$ FB1/kg. At day 28 post commencement of the feeding experiment, the erythrocytes count of fish fed diet D4 decreased from an earlier $3.15 \pm 0.04 \times 10^{6} / \mathrm{mm}^{3}$ at 14 days post commencement of the feeding to $2.99 \pm 0.38 \times 10^{6} / \mathrm{mm}^{3}$ while the erythrocytes count of fish fed diet D5 increased marginally from $3.87 \pm 0.14 \times 10^{6} / \mathrm{mm}^{3}$ at 14 days of feeding to $4.01 \pm 0.01 \times 10^{6} / \mathrm{mm}^{3}$ at day 28 . At day 56 of the dietary exposure, the erythrocytes count of fish fed diet D4 further decreased from $2.99 \pm 0.38 \times 10^{6} / \mathrm{mm}^{3}$ (value at day 28 ) to $2.98 \pm 0.02 \times 10^{6} / \mathrm{mm}^{3}$; while the erythrocytes counts of fish fed diet D5 decreased from $4.01 \pm 0.10 \times$ $10^{6} / \mathrm{mm}^{3}$ (at day 28 ) to $3.99 \pm 0.01 \times 10^{6} / \mathrm{mm}^{3}$.

Table 3 shows the leucocytes count of fishes exposed to dietary fumonisin B1 for 56 days. It shows after 7 days of the feeding experiment, the leucocytes counts of fish decreased to values between $18.08 \pm 1.09$ $\times 10^{3} / \mathrm{mm}^{3}$ (in fish fed diet D2) to $17.01 \pm 0.63 \times 10^{3} / \mathrm{mm}^{3}$ (in fish fed diet D5). One way ANOVA revealed the leucocytes counts of fish fed the FB1 amended diets to be significantly difference $(P<0.05)$ from those of fish fed the control diet (diet D1). further, Turkey-Kramer post hoc analysis revealed the leucocytes counts of fish fed the FB1 amended diets to be significantly different $(P<0.05)$ from one another. At 14 days, there were further reduction in the leucocytes counts of the fishes fed the diets amended with varied amounts of FB1 with fish fed diet D2 diets having a leucocytes count of $19.36 \pm 0.04 \times 10^{3} / \mathrm{mm}^{3}$ and fish fed diet D5 having a leucocytes count of $17.51 \pm 0.01 \times 10^{3} / \mathrm{mm}^{3}$. ANOVA revealed these values were significantly different $(P<$ $0.05)$ from those of fish fed the control diet. Turkey-Kramer post hoc shows that there were significant difference in the leucocytes counts of the fish fed the diets amended with varied amounts of FB1 at day 28 and 56 of the feeding experiment. 
Table 4 shows the haemoglobin concentration in blood of fish fed diets amended with varied amounts of fumonisin B1 for 56 days. It shows that at 7 days of feeding on the various diets, the haemoglobin concentration varied between $9.53 \pm 0.15 \mathrm{~g} / \mathrm{dl}$ (in fish fed the control diet) to $7.31 \pm 0.03 \mathrm{~g} / \mathrm{dl}$ (in fish fed diets D4). ANOVA reveals that except for fish fed diet D4, there was no significant difference $(P>0.05)$ in the haemoglobin concentration of fish fed the control diet and those fed diets amended with varied amounts of fumonisin B1. At day 14 of the feeding experiment, the haemoglobin concentration ranged from $8.97 \pm 0.01 \mathrm{~g} / \mathrm{dl}$ (in fish fed the control diet) to $10.15 \pm 0.13 \mathrm{~g} / \mathrm{dl}$ (in fish fed diet D5). ANOVA revealed, except for fish fed diet D5, the difference in the haemoglobin concentration of the fish fed the control diet and those fed the diets amended with varied amounts of fumonisin B1 were not statistically significant $(P>0.05)$.

At the $28^{\text {th }}$ day of the feeding trial, the haemoglobin concentration varied between $8.67 \pm 0.03 \mathrm{~g} / \mathrm{dl}$ (in fish fed $10 \mathrm{mg} \mathrm{FB} 1 / \mathrm{kg}$ ) to $9.61 \pm 0.13 \mathrm{~g} / \mathrm{dl}$ (in diet containing $82.77 \mathrm{mg} \mathrm{FB} 1 / \mathrm{kg}$ ). ANOVA revealed, there was no significant difference $(P>0.05)$ in the haemoglobin concentration in a comparison of fish fed the control diet with those fed the diets amended with varied amounts of fumonisin B1. At day 56 post commencement of the feeding trial, the haemoglobin concentration ranged from $9.01 \pm 0.01 \mathrm{~g} / \mathrm{dl}$ (in fish fed the control diet) to $5.38 \pm$ $0.14 \mathrm{~g} / \mathrm{dl}$ (in fish fed diet D5). ANOVA revealed there was a significant difference $(P<0.05)$ in the haemoglobin concentration of the blood of fish fed the control diet and those fed the diets amended with the varied amounts of fumonisin B1. Further, Turkey-Kramer post hoc analysis revealed that whereas, there was no significant difference $(P>0.05)$ in the haemoglobin concentration of fish fed diets containing 14.68, 24.74 and $43.04 \mathrm{mg}$ FB1/kg; there was a significant difference $(P<0.05)$ in the haemoglobin concentrations of fish fed these diets when compared to those fed the diet D5 $(82.77 \mathrm{mg} \mathrm{FB} 1 / \mathrm{kg})$.

Table 5 depicts the haematocrit of blood of juvenile Heterobranchuslongifilis catfish fed fumonisin B1 based diets for 56 days. It shows there was no significant difference $(P>0.05)$ in the haematocrit at 7 days of the feeding trial. At day 14 post commencement of the feeding, the haematocrit ranged from $26.84 \pm 0.10 \%$ (in fish fed the control feed) to $33.09 \pm 0.03 \%$ (in fish fed diet D5). ANOVA revealed a significant difference $(P<$ $0.05)$ in the haematocrit of the fish fed the control diet and those fed the diets amended with varied amounts of fumonisin B1. Further, Turkey-Kramer post hoc revealed, whereas there was no significant difference $(P>$ $0.05)$ in the haematocrit of fish fed diets D2 (14.68 mg FB1/kg) and D3 (24.74 mg FB1/kg), there was however, a significant difference $(P<0.05)$ in the haematocrit of fish fed these diets when compared with those of fish fed

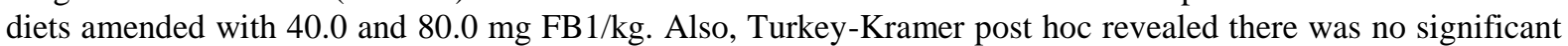
difference $(P>0.05)$ between the haematocrit of fish fed diets amended with $40.0 \mathrm{mgFB} 1 / \mathrm{kg}$ and haematocrit of fish fed diets amended with $80.0 \mathrm{mg} \mathrm{FB} 1 / \mathrm{kg}$.

At 28 days of dietary exposure to the FB1 amended diets, the haematocrit ranged from $28.22 \pm 0.06 \%$ (in fish fed the control diets) to $30.08 \pm 0.13 \%$ (in fish fed diets containing $14.68 \mathrm{mg} \mathrm{FB} 1 / \mathrm{kg}$ ). ANOVA revealed the haematocrit of the fish fed the control diet differs significantly $(P<0.05)$ from those of fish fed diets amended with varied amounts of fumonisin B1. Further, Turkey-Kramer post hoc analysis revealed the haematocrit of the fish fed the diets amended with the varied amounts of fumonisin B1 do not differ significantly $(P>0.05)$ from one another. At day 56 of the feeding experiment, the haematocrit ranged from $13.78 \pm 0.01 \%$ (in fish fed diet amended with $80.0 \mathrm{mg} \mathrm{FB} 1 / \mathrm{kg}$ ) to $25.98 \pm 0.04 \%$ (in fish fed the control diet). ANOVA revealed, a significant difference $(P<0.05)$ between the haematocrit of fish fed the control diet and the haematocrit of fish fed the diets amended with varied amounts of fumonisin B1. Turkey-Kramer post hoc analysis, revealed whereas the haematocrits of fish fed diets amended with 10.0, 20.0 and $40.0 \mathrm{mg}$ FB1/ $\mathrm{kg}$ do not differ significantly $(P>0.05)$, they however, significantly $(P<0.05)$ differ from those of fish fed diets amended with $80.0 \mathrm{mg}$ FB1/kg.

\subsection{Effects of Fumonisin $B_{1}$ Diets on Growth Performance of Heterobranchuslongifilis}

Table 5 shows results obtained for the growth performance of $H$. longifilis fed diets amended with varied amounts of FB1 for 56 days. It shows there were no significant differences $(P>0.05)$ in the mean initial total length and mean initial weight of the fish. The mean final length ranged between $31.01 \pm 1.38 \mathrm{~cm}$ (in fish fed diet amended with $80 \mathrm{mg} \mathrm{FB} 1 / \mathrm{kg}$ ) to $46.09 \pm 1.11 \mathrm{~cm}$ (in fishes fed the control diet $0.0 \mathrm{mg} \mathrm{FB} 1 / \mathrm{kg}$ ). ANOVA revealed a significant difference $(P<0.05)$ in the mean final length in a comparison of fishes fed the control diet and the fish fed the diets amended with varied amounts of FB1. Turkey-Kramer post hoc analysis, further revealed the mean final length of fish fed the diets amended with varied amounts of FB1 do not differ significantly $(P>0.05)$ from one another. Table 5 also shows the mean final weight of the fish fed the control diet $(2.37 \mathrm{mg}$ FB1/kg) differs significantly $(P<0.05)$ from those of fish fed the diets amended with varied amounts of FB1; Turkey-Kramer post hoc analysis, revealed the mean final weight of fish fed the diets amended with varied amounts of FB1 were not significantly different $(P>0.05)$ from one another.

Table 6 also shows the feed conversion ratio ranged between $0.42 \pm 0.01$ (in fish fed the control diet) to $1.93 \pm 0.01$ (in fish fed diets amended with $80.0 \mathrm{mg}$ FB1 $/ \mathrm{kg}$ ). The feed conversion ratio of fish fed the control diet differs significantly $(P<0.05)$ from those of fish fed the diets amended with varied amounts of FB1 (Table 
5). Turkey-Kramer post hoc analysis, showed whereas, the feed conversion ratio of fish fed diets amended with $10.0,20.0$ and $40.0 \mathrm{mg} \mathrm{FB} 1 / \mathrm{kg}$ were not significantly different $(P>0.05)$ from one another. They however, differ significantly $(P<0.05)$ when compared with those of fish fed diet amended with $80.0 \mathrm{mg}$ FB1/kg.

\subsection{Water quality parameter of the fish culture}

Results for the assessment of the fish culture water quality parameters are within the range prescribed for fresh water fishes and are as follows: the $\mathrm{pH}$ of the culture water ranges between 7.0 and 7.4; alkalinity ranged from $0.55 \mathrm{mmol} / \mathrm{L}$ to $0.70 \mathrm{mmol} / \mathrm{L}$; the nitrites concentration of the fish culture water ranged from 0.014 $\mathrm{mg} / \mathrm{L}$ to $0.048 \mathrm{mg} / \mathrm{L}$ while the nitrates concentration in the fish culture water ranged from $5.70 \mathrm{mg} / \mathrm{l}$ to 10.40 $\mathrm{mg} / \mathrm{L}$. Also, the dissolved oxygen concentration of the fish culture water ranged between $5.17 \mathrm{mg} / \mathrm{L}$ and 7.05 $\mathrm{mg} / \mathrm{L}$ while the temperature of the culture water ranged from $27.5^{\circ} \mathrm{C}$ to $30.8^{\circ} \mathrm{C}$ throughout the duration of the experiment.

\section{Discussion}

Results obtained from the present study showed that although the control diets was not amended with fumonisin, FB1 analysis of the diet revealed a fumonisin content of $2.37 \mathrm{mg} \mathrm{FB} 1 / \mathrm{kg}$ and the diets amended with $10.0 ; 20.0 ; 40.0$ and $80.0 \mathrm{mg} \mathrm{FB} 1 / \mathrm{kg}$ contained fumonisin B1 at $14.68 ; 24.74 ; 43.03$ and $82.77 \mathrm{mg} \mathrm{FB} 1 / \mathrm{kg}$ respectively; this finding was expected as previous reports have shown that maize is very frequently contaminated with various amounts of fumonisin B1 (Binder et al, 2007; Voss, 2007). At seven days of dietary fumonisin B1exposure, there was no change in the erythrocytes counts, haemoglobin concentration and the haematocrit values of juvenile Heterobranchuslongifilis catfish, although there were marginal increases in the erythrocyte count and haemoglobin concentration of fishes fed diet containing $43.04 \mathrm{mg}$ FB1/kg diet; however, at 14 days of dietary FB1 exposure, there was an increase in the erythrocyte count and haematocrit percentage in fishes fed amounts equal to or greater than $24.74 \mathrm{mg}$ FB1/ $/ \mathrm{kg}$ inclusion rate. A similar result was reported by Lumlerdatcha et al (1995), who noted an increase in the erythrocyte counts and haematocrit of Ictaluruspuntactus and concluded that the increases observed were within the haematological reference range for the species. The increase in the erythrocytes count as well as the haematocrit value recorded at 14 days of dietary FB1 exposure in this study however, exceeded the values for the haematological reference ranges reported for Clariasgariepinus (Adeyemo et al, 2014) and for Clariasgariepinus-Heterobranchuslongifilis hybrids (Okorie-Kanu and Unakalamba, 2015).This study also shows that at 14 days of dietary FB1 exposures, inclusion at rates less than $20 \mathrm{mg} \mathrm{FB} 1 / \mathrm{kg}$ did not elicit changes in the erythrocytes count and the haemoglobin concentrations; this was however, not the case with the haematocrit of the exposed fish, as inclusion rates of 10 mg FB1/kg caused an increase in the haematocrit of exposed fish. The increases in the haematological parameters may be physiopathological stress responses as the fish attempts to increase the amount of blood in peripheral circulation by increasing it effective erythrocytes number via splenic contraction (Fange, 1992; Ferguson, 1989). Again, inclusion rates of $40 \mathrm{mg} \mathrm{FB} 1 / \mathrm{kg}$ elicited the same erythrocytic response as in fishes fed $80 \mathrm{mg}$ FB1/kg. Whereas, there was no change in the haemoglobin concentration at day 28 of dietary FB1 exposure, the erythrocytes count and the haematocrit values decreased by the $56^{\text {th }}$ day of exposure when compared with values obtained at day 28 , although they remained elevated when compared with those of fish fed the control diets these pattern of change is suggestive of an adaptive response wherein the fish physiologically attempts to mitigate the stress effects of FB1 in the diets similar to the findings of Francis et al (2010).

Dietary FB1 caused a progressive leucocytopeania that was both dependent on the FB1 content of the diets as well as on the duration of feeding on the diets. Dietary FB1 has been reported to cause leucocytopeania in a number of other animal species (Gbore et al, 2010; Ewuola et al, 2008). Starting from day seven of dietary FB1 exposure, diets with fumonisin B1 inclusion rates equal to or more than $10 \mathrm{mg} F B 1 / \mathrm{kg}$ produced a progressive leucopeania in exposed juveniles of Heterobranchuslongifilis catfish; this is contrary to the findings of Lumlertdatcha et al (1995), who reported that dietary FB1 at concentrations less than $80 \mathrm{mg} \mathrm{FB} 1 / \mathrm{kg}$ did not affect the leucocytes counts in Ictaluruspunctatus.

In the feeding assays carried out in this study, the percentage length gain, percentage weight gain and the specific growth rate were significantly reduced by the presence of FB1 in the diets. The percentage length gain, percentage weight gain and specific growth rate (SGR) were significantly reduced when compared to those obtained for fish that were fed the control diet, whereas the feed conversion ratio (FCR) was significantly increased in fishes fed diets amended with FB1, implying dietary fumonisin B1 impaired growth performance in juvenile $H$. longifilis catfish; similar observations have been recorded in other fish species following dietary exposures to FB1 (Tuan et al, 2003; Lumletdatcha, et al, 1995). The results obtained in this study further shows that the deleterious effects of dietary exposures to FB1 on growth performance of $H$. longifilis was dependent on the amount of the Fumonisin B1 present in the diet. 
In conclusion, our findings indicates that diets containing fumonisin B1 levels less than or equal to $24.74 \mathrm{mg} \mathrm{FB} 1 / \mathrm{kg}$ produced the least pathologies and therefore recommended as the preferable tolerable limits for optimum haematologic parameters and growth performance in this catfish species.

\section{References}

[1]. Sepahdar, H.A Ebrahimzadeh, I. Sharifpour, A. Khorsaivi, A.A Motallebi, M. Mohseni, S. Kakoolati, H.R Pourali and A. Hallajian . Effects of different dietary levels of AFB1 on survival rate and growth factors of Beluga (Husohuso). Iranian Journal of Fisheries Science. 9 (1), 2009, 141-150.

[2]. A.G Francis, A.M Adewole, O Oginni, F Mercy, O Ayodeji, M. Bada M O. Akele. Growth performance, haematology and serum biochemistry of African catfish (Clariasgariepinus) fingerlings fed graded levels of dietary fumonisin B1. Mycotoxin Research. 26 (4), 2010, 221-227. DOI: 10.1007/s12550-010-0059-2

[3]. A.O Ayinla, Analysis of feeds and fertilizers for sustainable development in Nigeria. Nigerian Instutute of Oceanography and Marine Research (NIOMR) Techinical paper No.83.2007 13pp.

[4]. B.T Adeyemo and P.U Umeakuana. Some clinico-pathologic changes in Clariasgariepinus and Heterobranchuslongifilis catfishes following ethylene glycol toxicosis. Vom Journal of Veterinary Science 6 2011: 23-25

[5]. B.T Adeyemo, R.A. Obande and G.S Solomon. Haematological reference ranges of cultured Clariasgariepirus at the lower Benue River Basin Nigeria. Comparative Clinical Pathology 23(2) 2014: 361-366.

[6]. C.O Okorie-Kanu, N.J Unakalamba. Normal haematological and blood chemistry values of cultured Heteroclarias hybrids in South East Nigeria. Comparative Clinical Pathology, 24(3), 2015, 1015-1020

[7]. D. Tardieus, S.T Tran, A Auvergue, R. Babile, G. Benard, J.D Bailly and P. Guerre P. Effects of fumonsins on liver and kidney sphinganine and shinganine to sphingosine ratio during chronic exposure in ducks. Chemico-Biological Interactions 160, 2006, 5160 .

[8]. D.W Brown, C.P McCoy and G.E Rottinghaus. Experimental feeding of Fusarium moniliformes culture material containing fumonisin B1 to Channel catfish (Ictaluruspunctatus). Journal of Veterinary Diagnosis and Investigation. 6, 1994, 123-124

[9]. E.M Binder, L.M Tan, L.J Chin, J. Handle and J. Richard. Worldwide occurrence of mycotoxins in commodities, animal field and feed ingredients. In: DP Morgavi, R.T Riley, (Ed). Fusarium and their toxin: Mycology, Occurrence, Toxicity Control and Economic Impact. Animal Feed Science Technology. 2007, 127-139.

[10]. E.O Ewuola, F.A Gbore, J.T Ogunlade, R. Bandyopadhyay, J. Niegen and G.N Egbunike. Physiological response of rabbits bucks to dietary fumonisin: performance, haematology and serum biochemistry. Mycopathologia 165, 2008, 99-104

[11]. F.A Gbore, J.T Ogunlade, E.O Ewuola and G.N Egbunike. Growth indices and haematological parameters of weanling pigs fed dietary fumonisin B1. Nigeria Journal of Animal Production.37, 2010, 123-134.

[12]. F.O Walter and W.F.O Maracas. Discovery and occurrence of the fumonsins historical perspectives. Environmental Health 109, 2001:239- 243.

[13]. FMARD (Federal Ministry of Agriculture and Rural Development of Nigeria). Aquaculture Development. In: Presidential forum on the Fisheries Development subsector, Federal Department of Fisheries, Federal Ministry of Agriculture and Rural Development of Nigeria, Abuja Nigeria. October 2003, pp: 68.

[14]. H.W Ferguson. Spleen, blood, lymph, thymus and reticuloendothelial system. In: H.W Ferguson (Ed). Systemic pathology of fish. (Ames IA: Iowa State University Press, 1989) 90-103.

[15]. Harrison LF, Colvin BM, Greene JT, Newman LE, Cole Jr JR. (1990). Pulmonary edema and hydrothorax in swine produced by fumonisin B1, a toxic metabolite of Fusarium moniliforme. Journal of Veterinary Diagnosis and Investigation 2: 217-221.

[16]. J.T Ogunlade, F.A Gbore, E.O Ewuola, K.O Idahor, A.O Salako and G.N Egbunike. Biochemical and haematological responses of rabbits fed diets containing micro doses of Fumonisins. Tropical Journal of Animal Science. 7, 2004, 165-176

[17]. K.A Voss, G.W Smith and W.M Hashcek (2007) Fumonsins: Toxicokinetics, Mechanism of action and toxicity. Animal Feed Science and Technology 137, 2007, 299-325.

[18]. K.A Voss, R.T Riley and J Gelinaeu-van Waes J. Fumonisins. Reproductive and Developmental Toxicology. $2011 ; 725-737$.

[19]. L.O Tiamiyu, G.S Solomon and E.J Oketa. Effects of different boiling periods of Soyabean (Glycine max (L) Merill) on Growth, Performance of Tilapia (Oreochromisniloticus) fingerlings. Journal of Aquatic Science. 21 (1), 2006,15-18.

[20]. M.G Theumer, A.G Lopez, D.T Masih, S.N Chulze and H.R Rubinstein (2002). Immunological effects of fumonisin B1 in experimental subchronicmycotoxicoses in rats. Clinical Diagnosis and Laboratory Immunology. 9, 2002, $149-155$.

[21]. N.A Tuan, B.B Manning, R.T Lovell and G. Rottinghaus G. Responses of Nile Talapia (Oreochromisniloticus) fed diets containing different concentrations of momiliformin of fumonisin B1. Aquaculture 217, 2003, 515-528.

[22]. R Fange. Fish blood cells. In W.S Hoar, D.J Randall and A.P Farrell (Eds). Fish physiology, vol. 12B. (San Diego CA: Academic Press Inc. 1992). 1-54.

[23]. R.H. Rauber, P. Dilkin, A.O Mallman, A. Marchioro, C.A Mallman, A. Borsoi and V.P. Nascimento. Individual and combined effects of Salmonella typhimurium lipopolysaccharide and fumonisin B1 in broiler chickens. Poultry Science91, 2012, $2785-2791$.

[24]. R.J Roberts. Fish pathology. In Ronald J Roberts (Ed). Fish pathology Third edition. (WB Saunders, Edinburgh 2012). 359

[25]. R.T Riley and K.A Voss. Differential sensitivity of rat kidney and liver to fumonsin toxicity: Organ-specific difference in toxin accumulation and sphingoid base metabolism. Toxicological Science 92, 2006, 235-245.

[26]. S. Knowles, T.C Hrubec, S.A Smith and R.S Bakal. Haematology and plasma chemistry reference intervals for cultured short Nose Sturgeon (Acipenserbrevirostrum). Veterinary Clinical Pathology35, 2006, 434- 440

[27]. S. Lumlertdacha, R.T Lovell, R.A Shelby, S.D Lenz and B.W Kemppainen. Growth, haemetology and histopathology of channel catfish (Ictaluruspunctatus), feed toxins from, Fusarium monilforme. Aquaculture 130, 1995, 201-218.

[28]. S. Pepeljnjak, Z. Petrinec, S Kovacic and M. Segvic. Screening toxicity study in young carp (Cyprinuscarpio) on feed amended with fumonisin B1. Mycopathologia. 156, 2003, 139-145.

[29]. S.A. Bankole and O.0 Mabekoje. Occurrence of aflatoxins and fumonisins in pre-harvest maize from south-western Nigeria. Food Additives and Contaminants 21 2004:251-255.

[30]. S.C Bezuidenhout, WCA Gelderblom, C.P Gorst-Allman, R.M Horak, WFO Marasas, G. Spiteller and R Vleggar. Structure elucidation of the Fumonisins, mycotoxins from Fusarium moniliforme. Journal of Chemical Society and Chemical Communication. 11 1988: 743-745

[31]. T. Arnanson, B.R BjRnsson, A. Steinarsson, and M. Oddgeisson. Effects of temperature and body weight on growth rate and feed conversion ratio in Turbot (Scohthalmusmaximus). Aquaculture. 295 2009:218-225

[32]. T. W Campbell. Haematology of fish. In: Troy D.B (Ed.), Veterinary haematology and Clinical Chemistry. (Baltimore, USA: Lippincott. Williams and Wilkins 2004). 277-289. 
Effects of Dietary Fumonisin B1 on Haematology and Growth Performance of the Clariid Fishhe..

[33]. T.W Campbell. Haematology of fish. In: M.A Thrall, G Weiser, R Allison (Eds). Veterinary Haematology and Clinical Chemistry. (Ames IA: John Wiley \& Sons, 2012). 293-312.

[34]. W.F Marasas. Discovery and occurrence of the fumonisins: a historical perspective. Environmental Health 2, 2001, 239-243.

[35]. W.M Hascheck, K.A Voss and V.R Beasley. Selected mycotoxins affecting animal and human health. In Handbook of Toxicologic Pathology. In: W.M Haschek, C.G Roussex, and M.A Wallig (Eds,) $2^{\text {nd }}$ edition. (Academic Press, New York, 2001). 645-698.

[36]. Z. Petrinec, S. Pepeljnjak, S. Kovacic and A. Krznavic A. Fumonisin B1 causes multiple lesions in common carp (Cyprinuscarpio). Deutsche TierarztvicheWonchenschnift. 111, 2004, 358-363

Table 1 Diet composition, Fumonisin B1 content and proximate analysis of formulated diets

\begin{tabular}{|l|l|l|l|l|l|}
\hline \multirow{2}{*}{ Parameter } & \multicolumn{5}{|c|}{ FUMONISIN B1 AMENDED DIETS } \\
\cline { 2 - 6 } & $\begin{array}{l}\text { D1 (0.0 mg } \\
\text { FB1/kg) }\end{array}$ & $\begin{array}{l}\text { D2 }(10.0 \mathrm{mg} \\
\text { FB1/kg) }\end{array}$ & $\begin{array}{l}\text { D3 (20.0 mg } \\
\text { FB1/kg) }\end{array}$ & $\begin{array}{l}\text { D4 (40.0 mg } \\
\text { FB1/kg) }\end{array}$ & $\begin{array}{l}\text { D5 }(80.0 \mathrm{mg} \\
\text { FB1/kg) }\end{array}$ \\
\hline Fish meal (\%) & 19.00 & 19.00 & 19.00 & 19.00 & 19.00 \\
\hline Soybean cake (\%) & 37.00 & 37.00 & 37.00 & 37.00 & 37.00 \\
\hline Maize (\%) & 32.00 & 32.00 & 32.00 & 32.00 & 32.00 \\
\hline Palm oil (\%) & 1.00 & 1.00 & 1.00 & 1.00 & 1.00 \\
\hline Fish oil (\%) & 3.00 & 3.00 & 3.00 & 3.00 & 3.00 \\
\hline Vit/min Premix (\%) & 0.50 & 0.50 & 0.50 & 0.50 & 0.50 \\
\hline Bone meal (\%) & 1.00 & 1.00 & 1.00 & 1.00 & 1.00 \\
\hline NaCl (\%) & 0.23 & 0.25 & 0.25 & 0.25 & 0.25 \\
\hline Fumonisin B1 & 2.37 & 14.68 & 24.74 & 43.04 & 82.77 \\
\hline Starch Binder (\%) & 2.00 & 2.00 & 2.00 & 2.00 & 2.00 \\
\hline Crude Protein (\%) & 40.01 & 40.00 & 40.04 & 40.01 & 40.02 \\
\hline Gross Energy (kj/g) & 19.77 & 20.00 & 20.01 & 19.86 & 20.00 \\
\hline Digestible Energy (kj/g) & 19.00 & 19.01 & 18.98 & 19.01 & 19.10 \\
\hline Total Lipids (\%) & 9.00 & 9.00 & 9.00 & 9.00 & 9.00 \\
\hline Moisture (\%) & 2.30 & 2.30 & 2.30 & 2.30 & 2.30 \\
\hline Ash (\%) & 9.72 & 9.70 & 9.7 & 9.69 & 9.58 \\
\hline
\end{tabular}

Table 2 Erythrocyte count $\left(\times 10^{6} / \mathrm{mm}^{3}\right)$ of Heterobranchuslongifiliscatfish juveniles fed varied levels of fumonisin B1 (FB1).

\begin{tabular}{|l|ll|l|l|l|l|}
\hline \multirow{2}{*}{ Days in feeding } & \multicolumn{6}{|c|}{ FUMONININ B1 AMENDED DIETS } \\
\cline { 2 - 7 } & $\begin{array}{l}\text { D1 }(0.0 \\
\text { FB1/kg) }\end{array}$ & $\begin{array}{l}\text { D2 }(10.0 \mathrm{mg} \\
\text { FB1/kg) }\end{array}$ & $\begin{array}{l}\text { D3 (20.0 mg } \\
\text { FB1/kg) }\end{array}$ & $\begin{array}{l}\text { D4 (40.0 mg } \\
\text { FB1/kg) }\end{array}$ & $\begin{array}{l}\text { D5 (80.0 mg } \\
\text { FB1/kg) }\end{array}$ \\
\hline 7 & $2.03 \pm 0.06^{\mathrm{a}}$ & $2.53 \pm 0.03^{\mathrm{a}}$ & $2.50 \pm 0.01^{\mathrm{a}}$ & $3.40 \pm 0.01^{\mathrm{a}}$ & $3.66 \pm 0.02^{\mathrm{a}}$ \\
\hline 14 & $2.17 \pm 0.01^{\mathrm{a}}$ & $2.88 \pm 0.10^{\mathrm{a}}$ & $2.88 \pm 0.09^{\mathrm{a}}$ & $3.51 \pm 0.04^{\mathrm{b}}$ & $3.87 \pm 0.14^{\mathrm{b}}$ \\
\hline 28 & $2.33 \pm 0.01^{\mathrm{a}}$ & $2.52 \pm 0.02^{\mathrm{a}}$ & $2.61 \pm 0.02^{\mathrm{a}}$ & $2.99 \pm 0.38^{\mathrm{b}}$ & $4.10 \pm 0.10^{\mathrm{c}}$ \\
\hline 56 & $2.46 \pm 0.01^{\mathrm{a}}$ & $2.60 \pm 0.01^{\mathrm{a}}$ & $2.75 \pm 0.03^{\mathrm{a}}$ & $2.98 \pm 0.02^{\mathrm{b}}$ & $3.99 \pm 0.01^{\mathrm{c}}$ \\
\hline
\end{tabular}

${ }^{\mathrm{a}, \mathrm{b}, \mathrm{c}}$ Within a row, means without a common superscript differ $(P<0.05)$.

Table 3 Leucocytes count $\left(\times 10^{3} / \mathrm{mm}^{3}\right)$ of Heterobranchuslongifilis catfish juvenilesfed varied levels of fumonisin B1 (FB1).

\begin{tabular}{|l|l|l|l|l|l|}
\hline \multirow{2}{*}{ Days in feeding } & \multicolumn{5}{|c|}{ FUMONISIN B1 AMENDED DIETS } \\
\cline { 2 - 7 } & $\begin{array}{l}\text { D1 }(0.0 \\
\text { FB1/kg })\end{array}$ & $\begin{array}{l}\text { D2 }(10.0 \mathrm{mg} \\
\text { FB1/kg) }\end{array}$ & $\begin{array}{l}\text { D3 }(20.0 \mathrm{mg} \\
\text { FB1/kg) }\end{array}$ & $\begin{array}{l}\text { D4 (40.0 mg } \\
\text { FB1/kg) }\end{array}$ & $\begin{array}{l}\text { D5 }(80.0 \mathrm{mg} \\
\text { FB1/kg) }\end{array}$ \\
\hline 7 & $22.43 \pm 1.16^{\mathrm{a}}$ & $18.08 \pm 1.09^{\mathrm{b}}$ & $18.17 \pm 0.88^{\mathrm{b}}$ & $17.23 \pm 0.82 \mathrm{~b}$ & $17.01 \pm 0.63^{\mathrm{b}}$ \\
\hline 14 & $21.95 \pm 0.01^{\mathrm{a}}$ & $19.36 \pm 0.04^{\mathrm{b}}$ & $19.22 \pm 0.03^{\mathrm{c}}$ & $18.85 \pm 0.03^{\mathrm{c}}$ & $17.51 \pm 0.01^{\mathrm{c}}$ \\
\hline 28 & $20.17 \pm 0.01^{\mathrm{a}}$ & $13.31 \pm 0.10^{\mathrm{b}}$ & $13.60 \pm 0.07^{\mathrm{b}}$ & $12.55 \pm 0.38^{\mathrm{b}}$ & $10.63 \pm 0.01^{\mathrm{c}}$ \\
\hline 56 & $20.08 \pm 0.03^{\mathrm{a}}$ & $10.64 \pm 0.01^{\mathrm{b}}$ & $10.23 \pm 0.01^{\mathrm{b}}$ & $9.08 \pm 0.09^{\mathrm{b}}$ & $7.11 \pm 0.11^{\mathrm{c}}$ \\
\hline
\end{tabular}

${ }^{\mathrm{a}, \mathrm{b}, \mathrm{c}}$ Within a row, means without a common superscript differ $(P<0.05)$.

Table 4.Haemoglobin concentration $(\mathrm{g} / \mathrm{dl})$ of blood of Heterobranchuslongifilis catfish juveniles fed varied levels fumonisin B1 (FB1).

\begin{tabular}{|l|l|l|l|l|l|}
\hline \multirow{3}{*}{ Days in feeding } & \multicolumn{7}{|c|}{ FUMONISIN B1 AMENDED DIETS } \\
\cline { 2 - 7 } & $\begin{array}{l}\text { D1 (0.0 mg } \\
\text { FB1/kg) }\end{array}$ & $\begin{array}{l}\text { D2 }(10.0 \mathrm{mg} \\
\text { FB1/kg) }\end{array}$ & $\begin{array}{l}\text { D3 (20.0 mg } \\
\text { FB1/kg) }\end{array}$ & $\begin{array}{l}\text { D4 (40.0 mg } \\
\text { FB1/kg) }\end{array}$ & $\begin{array}{l}\text { D5 }(80.0 \mathrm{mg} \\
\text { FB1/kg) }\end{array}$ \\
\hline 7 & $9.53 \pm 0.15^{\mathrm{a}}$ & $8.71 \pm 0.01^{\mathrm{a}}$ & $8.60 \pm 0.10^{\mathrm{a}}$ & $7.31 \pm 0.03^{\mathrm{b}}$ & $9.63 \pm 0.09^{\mathrm{a}}$ \\
\hline 14 & $8.97 \pm 0.01^{\mathrm{a}}$ & $8.93 \pm 0.02^{\mathrm{a}}$ & $9.03 \pm 0.02^{\mathrm{a}}$ & $9.40 \pm 0.07^{\mathrm{a}}$ & $10.15 \pm 0.13^{\mathrm{b}}$ \\
\hline 28 & $8.95 \pm 0.01^{\mathrm{a}}$ & $8.67 \pm 0.03^{\mathrm{a}}$ & $8.88 \pm 0.02^{\mathrm{a}}$ & $8.90 \pm 0.11^{\mathrm{a}}$ & $9.61 \pm 0.13^{\mathrm{a}}$ \\
\hline 56 & $9.01 \pm 0.01^{\mathrm{a}}$ & $7.80 \pm 0.03^{\mathrm{b}}$ & $7.09 \pm 0.10^{\mathrm{b}}$ & $7.10 \pm 0.12^{\mathrm{b}}$ & $5.38 \pm 0.14^{\mathrm{c}}$ \\
\hline
\end{tabular}

${ }^{\mathrm{a}, \mathrm{b}, \mathrm{c}}$ Within a row, means without a common superscript differ $(P<0.05)$. 
Effects of Dietary Fumonisin B1 on Haematology and Growth Performance of the Clariid Fishhe..

Table 5. Packed cell volume (\%) of blood of Heterobranchuslongifilis catfish juveniles fed varied levels of fumonisin B1 (FB1).

\begin{tabular}{|l|l|l|l|l|l|}
\hline \multirow{2}{*}{ Days in feeding } & \multicolumn{7}{|c|}{ FUMONISIN B1 AMENDED DIETS } \\
\cline { 2 - 7 } & $\begin{array}{l}\text { D1 }(0.0 \quad \mathrm{mg} \\
\text { FB1/kg) }\end{array}$ & $\begin{array}{l}\text { D2 }(10.0 \mathrm{mg} \\
\text { FB1/kg) }\end{array}$ & $\begin{array}{l}\text { D3 }(20.0 \quad \mathrm{mg} \\
\text { FB1/kg) }\end{array}$ & $\begin{array}{l}\text { D4 (40.0 mg } \\
\text { FB1/kg })\end{array}$ & $\begin{array}{l}\text { D5 } \\
\text { FB1/kg })\end{array}$ \\
\hline 7 & $27.03 \pm 0.04^{\mathrm{a}}$ & $26.44 \pm 0.03^{\mathrm{a}}$ & $26.51 \pm 0.03^{\mathrm{a}}$ & $27.08 \pm 0.10^{\mathrm{a}}$ & $27.31 \pm 0.16^{\mathrm{a}}$ \\
\hline 14 & $26.84 \pm 0.10^{\mathrm{a}}$ & $31.17 \pm 0.16^{\mathrm{b}}$ & $31.29 \pm 0.24^{\mathrm{b}}$ & $32.66 \pm 0.11^{\mathrm{c}}$ & $33.09 \pm 0.30^{\mathrm{c}}$ \\
\hline 28 & $28.22 \pm 0.06^{\mathrm{a}}$ & $30.08 \pm 0.13^{\mathrm{b}}$ & $29.56 \pm 0.10^{\mathrm{b}}$ & $30.03 \pm 0.11^{\mathrm{b}}$ & $29.40 \pm 0.10^{\mathrm{b}}$ \\
\hline 56 & $25.98 \pm 0.04^{\mathrm{a}}$ & $22.47 \pm 0.06^{\mathrm{b}}$ & $22.51 \pm 0.14^{\mathrm{b}}$ & $19.93 \pm 0.11^{\mathrm{b}}$ & $13.78 \pm 0.01^{\mathrm{c}}$ \\
\hline
\end{tabular}

${ }^{\mathrm{a}, \mathrm{b}, \mathrm{c}}$ Within a row, means without a common superscript differ $(P<0.05)$.

Table 6 Growth performance of Heterobranchuslongifilis catfish juveniles fed varied levels of fumonisin B1 (FB1) for 56 days.

\begin{tabular}{|c|c|c|c|c|c|}
\hline \multirow[b]{2}{*}{ Parameter } & \multicolumn{5}{|c|}{ FUMONISIN B1 AMENDED DIETS } \\
\hline & $\begin{array}{l}\text { D1 }(0.0 \quad \mathrm{mg} \\
\text { FB1 } / \mathrm{kg})\end{array}$ & $\begin{array}{l}\text { D2 (10.0 mg } \\
\text { FB1 } / \mathrm{kg})\end{array}$ & $\begin{array}{l}\text { D3 (20.0 mg } \\
\text { FB1/kg) }\end{array}$ & $\begin{array}{l}\text { D4 }(40.0 \mathrm{mg} \\
\text { FB1 } / \mathrm{kg})\end{array}$ & $\begin{array}{l}\text { D5 (80.0 } \mathrm{mg} \\
\text { FB 1/kg) }\end{array}$ \\
\hline $\begin{array}{l}\text { Mean initial total } \\
\text { length }(\mathrm{cm})\end{array}$ & $28.10 \pm 0.10^{\mathrm{a}}$ & $27.0 \pm 1.39^{\mathrm{a}}$ & $28.6 \pm 1.41^{\mathrm{a}}$ & $29.00 \pm 0.93^{\mathrm{a}}$ & $27.70 \pm 0.66^{\mathrm{a}}$ \\
\hline $\begin{array}{l}\text { Mean final total } \\
\text { length }(\mathrm{cm})\end{array}$ & $46.09 \pm 1.11^{\mathrm{a}}$ & $32.49 \pm 1.07^{b}$ & $32.60 \pm 0.56^{\mathrm{b}}$ & $31.31 \pm 1.38^{\mathrm{b}}$ & $31.01 \pm 1.38^{b}$ \\
\hline $\begin{array}{l}\text { Mean length gain } \\
(\%)\end{array}$ & $17.99 \pm 1.01^{\mathrm{a}}$ & $5.49 \pm 1.21^{\mathrm{b}}$ & $4.00 \pm 0.67^{b}$ & $3.07 \pm 0.09^{b}$ & $3.31 \pm 0.44^{b}$ \\
\hline $\begin{array}{l}\text { Mean initial weight } \\
(\mathrm{g})\end{array}$ & $143.09 \pm 1.37^{\mathrm{a}}$ & $141.64 \pm 2.11^{\mathrm{a}}$ & $142.07 \pm 1.33^{\mathrm{a}}$ & $142.61 \pm 0.93^{\mathrm{a}}$ & $141.78 \pm 1.27^{\mathrm{a}}$ \\
\hline $\begin{array}{l}\text { Mean final weight } \\
(\mathrm{g})\end{array}$ & $187.31 \pm 1.60^{\mathrm{a}}$ & $170.30 \pm 0.99^{\mathrm{b}}$ & $170.68 \pm 0.16^{\mathrm{b}}$ & $169.43 \pm 1.02^{b}$ & $165.09 \pm 1.69^{b}$ \\
\hline $\begin{array}{l}\text { Mean gain in } \\
\text { weight }(\%)\end{array}$ & $44.22 \pm 1.38^{\mathrm{a}}$ & $28.66 \pm 0.31^{\mathrm{b}}$ & $28.61 \pm 0.71^{\mathrm{b}}$ & $26.82 \pm 1.04^{b}$ & $23.31 \pm 1.13^{\mathrm{c}}$ \\
\hline SGR (\% /day) & $0.49 \pm 0.01^{\mathrm{a}}$ & $0.33 \pm 0.01^{\mathrm{b}}$ & $0.33 \pm 0.04^{\mathrm{b}}$ & $0.31 \pm 0.02^{\mathrm{b}}$ & $0.27 \pm 0.02^{\mathrm{b}}$ \\
\hline FCR & $0.42 \pm 0.01^{\mathrm{a}}$ & $0.88 \pm 0.00^{\mathrm{b}}$ & $1.03 \pm 0.01^{\mathrm{b}}$ & $1.12 \pm 0.20^{\mathrm{b}}$ & $1.93 \pm 0.01^{\mathrm{c}}$ \\
\hline
\end{tabular}

${ }^{\mathrm{a}, \mathrm{b}, \mathrm{c}}$ Within a row, means without a common superscript differ $(P<0.05)$.

SGR represent specific growth rate; FCR represent feed conversion ratio. 